Jensen, Meg (2018) How art constitutes the human: aesthetics, empathy, and the interesting in autofiction. In: Dix, Hywel, (ed.) Autofictions in English. London, U.K. : Palgrave Macmillan. pp. 6583. reproduced with permission of Palgrave Macmillan.

This extract is taken from the author's original manuscript and has not been edited. The definitive, published, version of record is available here: https://link.springer.com/book/10.1007\%2F978-3319-89902-2 
How art constitutes the Human: Aesthetics, Literary Empathy, and the Interesting in Autofiction

Dr Meg Jensen, Centre for Life Narratives, Kingston University

\section{The Erasure of the Individual}

In Rachel Cusk's 2014 novel, Outline, the nearly invisible narrator (whose name we discover in passing to be Faye) reflects on the music collection she finds in the furnished apartment she is renting in Athens. The flat's owner, Clelia, is unknown to Faye, who speculates on her mind-set: 'I wasn't sure I would choose to sit through symphony after symphony,' Faye states, 'any more than I would spend the afternoon reading the Encylopaedia Brittanica.' It then occurs to her that:

in Clelia's mind they perhaps represented the same thing, a sort of objectivity that arose when the focus became the sum of human parts and the individual was blotted out. It was, perhaps, a form of discipline, almost of asceticism, a temporary banishing of the self and its utterances (54).

In Outline, Cusk goes on to enact precisely the disciplinary, ascetic process she describes herefocussing on the 'sum of' humanity and erasing traditional forms of individual life story-telling such as memoir and imaginative fiction (both genres in which Cusk has previously excelled).

Outline - at once autobiographical, fictive and fictionalised - engages our interest by occupying the space across those increasingly unstable generic boundaries. But it also articulates the aesthetic of the discourse used to debate between individual and system: the category of the interesting. In doing so, Cusk's novel is emblematic of a wave of writing by authors from Vladimir Nabakov to Elfriede Jelinek to Jamaica Kincaid to J.M. Coetzee to Louise Erdrich that may more readily be aligned with the Francophone tradition of autofiction than with works of autobiographically-based 
fiction that resemble the traditional Bildungsroman. Cusk's attempt to 'blot out' the individual from the autobiographical in order 'to focus' on 'the sum of human parts,' moreover, may have wider implications beyond the transgression of generic literary boundaries.

In an essay published in 2009, James Dawes asked 'How does art constitute the human, and what implications does this have for human rights?' In this chapter I will argue that the genre tension and narrative and authorial ambiguity inherent in post-modern autofiction provides a space for interrogating the complex ways that art constitutes the human and speculate on the implications of this idea for the advancement or otherwise of human rights. Dawes's most recent consideration of the relationship between 'Human Rights, Literature and Empathy,' complicates the notion that empathy, in and of itself, is a worthy goal in the service of rights advancement. As he argues, 'a powerful, important story' that informs 'the work of human rights' is that 'literature promotes empathy, and empathy promotes rights' (427). Dawes's own research suggests, however, that a causal connection between empathy and rights should not be taken for granted. He demonstrates that both rights workers and literary scholars are conflicted over the role that literature can play in increasing empathy and whether such empathy leads to useful action. Some examples of views Dawes collected follow:

1. Generating empathy in distant spectators is the first and most important step in addressing human rights violations. Human rights is [...] nothing more than the historical expansion of our capacity to empathize: expanding our circle of concern beyond our kin, our community, our region, our religion, our nation-state.

2. Generating empathy in distant spectators is ineffective and sometimes counterproductive for addressing human rights violations. When empathy-inspired action cannot quickly find a clear, straightforward, and personalizing solution, it fades, 
and the unpleasant (guilty, helpless) sensation of fading promotes sympathy-avoidance in the future. (429)

From literary scholars, Dawes collected similarly contradictions: stories 'generate empathy, and empathy generates helping behaviours,' on the one hand, and 'actively interfere with real world empathy' (430-1) on the other. He further notes that it was not unusual for him to find the same person holding such mutually-exclusive beliefs and concludes this inconclusive comparison, with a swerve towards an appreciation of the empathic qua empathic. 'Scholars who focus upon the way literary empathy transfers from the reader to the external world,' he states, 'would make empathy a hostage to cause and consequence and thus miss the point of literary ethics.' He ends with a definition of what he terms 'literary empathy,' which 'does not point past the reader. It points to the reader' (431), and it need not have impact in the 'real world' to be of value.

A similar construction of empathy might be said to inform contemporary works of autofiction. Recently, Catherine Cusset, a well-known author of French autofiction, considered the dynamics of her practice and the mechanisms that generate affective responses from readers. Autofiction, Cusset writes, demands:

the capacity to go back inside an emotion. To erase anything anecdotic that wouldn't be part of that emotion and would water it down, in order to offer it to the reader in a bare form, devoid of anything too idiosyncratic, so that he can claim it as his own. When the writer reaches a deep enough level of emotion, it becomes anybody's emotion: something universal. (2)

Can any life experience, though, however it be formed and disseminated, really claim to provoke 'universality' of empathic response? If so, the aims of autofiction may be complicated by the same 
'question of cultural imperialism - identity politics writ large' that James Dawes argues is 'ever present in human rights discourse' (401). This ingrained power dynamic is obscured, he claims, by the return of 'aesthetics as a category of interest' through which identity politics are hidden. Aesthetic judgements of universal value, that is, risk effacing the 'idiosyncratic' experience of the individual in the 'attempt to fortify the return to universalizing humanism' (399). What is needed instead, he argues, is a politics of aesthetic judgement that, rather than 'exploring the relationship between art and the promotion of human dignity, interrogates it,' by asking why and how cultural artefacts like novels 'train individuals and communities to perceive and judge racial, sexual or gender difference' (400). As the reflections of Cusset and the fictional Faye suggest, this aesthetic interrogation of style, form, and language is hard at work in contemporary autofiction.

Elsewhere, I have written on the complex relations surrounding life narratives and the advancement of human rights. ${ }^{1}$ This interface between storytelling and recovery, testimony and justice is not only a contested moral and ethical space, but a location of aesthetic practice and theory. Indeed, both Lynn Hunt (Inventing Human Rights: A History, 2007) and Joseph Slaughter (Human Rights, Inc. 2007) have argued that the human rights movement was informed by developments in literary discourse and narrative practice. As Dawes explains, the novel may be seen as:

an artistic form that is dependent upon a certain conception of the human (individualistic, autonomous, defined less by status than by valuable interior feelings which, implicitly, all can share) - a conception that is likely also a prerequisite for the modern, liberal conception of (natural, equal, and universal) human rights. (397)

\footnotetext{
${ }^{1}$ See in Cited Works List, Meg Jensen (2014), (2015), (2017).
} 
Because of this conceptual link, Dawes views the current interest in the relation between life narratives and human rights discourse as 'best understood within the larger context of aesthetics and ethics in intellectual history, in the broad study of the way art provides a foundation for human dignity' (397). In Human Rights, Inc., Slaughter similarly argues that as the Bildungsroman developed alongside human rights law, it became 'a novelistic correlative to the socialising project' of those laws (41), defining human rights in specific and circumscribed ways. In doing so, it constitutes 'the predominant formal literary technology in which social outsiders narrate affirmative claims for inclusion in a regime of rights and responsibilities' (22).

In 'Autobiography in the English Bildungsroman,' Jerome Buckley argued that historically, this form has drawn upon the real-life trials, tribulations and triumphs of its authors. Nevertheless, it has done so by following an uncannily formulaic structure that seems at odds with the genre's presumed privileging of the individual. In fact, despite the influence of each writer's very different life experiences, the lives of the protagonists of the Bildungsroman tend to follow a similar trajectory. Traditionally, as Slaughter demonstrates, the narrator/protagonist begins 'as a rightless individual and moves towards a socially restorative resolution in which s/he becomes a rightsbearing citizen incorporated into the state' (41). Moreover, this incorporation is neither wholly benign nor clearly drawn as 'the person that emerges is [. . .] a persona ficta, an often incoherent, self-contradictory, improbable figure' (19-20). Therefore, Slaughter argues, 'literary and cultural forms' 'constitute and regulate' society (4). If this is so, then the normative rights-personality imagined by the 'mutually enabling fictions' (4) of human rights law and the Bildungsroman also gives rise to 'the rightless and marginal' who lacks 'what the incorporated citizen-subject enjoys' (43). Through its relation to rights law, in other words, the Bildungsroman, privileges a certain type of human experience as having universal value and deserving human dignity. 
Samera Esmeir has similarly argued that rights law transforms 'humanity into a juridical status, which precedes, rather than follows and describes, all humans' (1544). In doing so, the law may be seen to constitute (rather than identify) humanity, establishing 'a human who would otherwise remain nonhuman' (1544). Through such erasure of 'all other humanities' Esmeir notes, the law not only succeeds 'in imposing its particular vision of humanity but also [...] in erasing their past existence before the law's intervention' (1547). The Bildungsroman may be read as colluding in such erasure, as 'a powerful ally in naturalizing the law's [. . .] ambiguity and ambivalence' (Slaughter 44), whose 'particular vision of humanity' (Sameir 1547) is linked directly to the legal, juridical status of citizen-subjects and thereby effaces alternative forms. This ambiguous identity politics is likewise found in the often unclear, unstable, and/or intertwined functions of author, narrator, protagonist and reader in contemporary works of autofiction.

Catherine Cusset argues that 'the "I" of the autofiction writer is anything but egocentric. It is not centred on the self, but erasing the self so as to make the truth of past emotion emerge' (2). That autofiction demands a process of self-erasure is confirmed by her fellow novelist, Camille Laurens, who notes that in such works 'I, it's not me, it's each of us' (141). Just as Cusk's narrator attempts to insinuate herself into the mind of Clelia, the flat-owner, to understand her preoccupation with one form of art over any other, autofiction aims to formulate a distinct kind of human subject, one whose intersubjectivity (I, me, us) generates a kind of aesthetic intimacy. This intimacy recalls Dawes' 'literary empathy': a readerly experience of compassion that may, or may not, lead to rights-advancing action. Such narrative techniques reflect specific rhetorical choices that are worth interrogating. As Dawes asks, 'what makes these acts of storytelling more or less effective in changing the world?' (402) 
In ruminating on her autofictive practice, Cusset notes that 'I didn't know where I was going [...] I just knew that there was something interesting there' (4, my emphasis). This curious definition of the interesting is echoed in the work of Sianne Ngai, whose recent study Our Aesthetic Categories (2012) argues that in postmodernity, 'interest begins as a feeling of not knowing exactly what we are feeling' (135). The interesting as an aesthetic category, in other words, is an unstable judgement, a process rather than a destination. Cusset mirrors this idea as she states that despite her feeling of interest as she wrote, 'what I was writing about was quite banal.' What interested Cusset was the act of 'excavation.' 'It was,' she states, 'only the exhaustive character of the quest that could make it interesting. Exposing everything, not excluding anything' (5). As we shall see, the interesting is a not an instant judgement but an iterative one, unfolding in the process of comparison, justification and communication. Autofiction, with its complex transgressions across language, time, narrative viewpoint, agency, identity and genre, comprises a singularly interesting form of life story-telling. As such, this hybrid form may be a singularly effective space for disseminating autobiographical revelations that can be judged of 'interest' to others. This aesthetic, iterative, judgement of interesting, moreover, may generate a new kind of empathy necessary to increase human connectivity among increasingly information-overloaded humanity.

\section{Genre, Language and Meaning}

If we are to consider the relation between aesthetics and world-changing narrative practices, our first concern may be literary genre itself. Karen Ferreira-Meyers has noted that 'genre does not only produce and interpret the facts of language, it can also 'rate' or situate them within the field of discourse' (8). Cusset likewise sees the practice of autofiction as centrally focussed on linguistic and generic concerns. 'The only fiction in autofiction is the work on language,' she states. 'The facts are real and the project is to reach a certain truth' (2). Ferreria-Meyers similarly characterises 
autofiction as 'an oxymoronic pact or contradictory contract involving two opposite types of narratives: it is a narrative based, as autobiography, on the principle of the three identities (the author is also the narrator and main character), which however claims to be fiction in its narrative and in terms of its peritextual allegations (title, back cover)' (204). Serge Doubrovsky first argued that autobiography 'is a privilege reserved for the important people of this world, at the end of their lives' (10), whereas autofiction is '[f]iction of strictly real events or facts [...] of having entrusted the adventure of language with the language of an adventure, outside the wisdom of the traditional' (10). Ferreira-Meyers puts it more simply. Autofiction, she notes 'fictionalises a character who really lived,' and in doing so it can only 'exist as an independent literary category if it exemplifies hybridity' (205).

While the traditional Bildungsroman offers a version of the dignified human as what Slaughter calls an incorporated citizen-subject, the hybridity of autofiction enables multiple, contradictory, disenfranchised and unstable representations of humanity. In doing so it increases the potential range of that which constitutes the human and is possessed of human dignity. As Philippe Forest has argued, the significance of autofiction is its response competing aesthetic impulses and pressures: 'the imperative to represent reality' on the one hand, and to 'be an answer to reality,' on the other (137). Similarly, Christiane Chaulet-Achour conceives the representation of conflicts between truth and fiction to be the aesthetic aim of autofiction. These pressures present opportunities rather than challenges, she argues as 'the rights to imagination are at least as strong as those of testimony, where the poetic function overwhelms, works, transforms and reveals the testimonial function' (116). We can see this imaginative transformation and revelation of testimony particularly clearly where autofictions rely, as they often do, on para textual elements. Such material serves to legitimate the socio-historical contexts of autofictional narratives while 
simultaneously highlighting their 'textuality' and status as 'discourse' rather than truth (FerreiraMeyers 209).

This textualising of identity is a central characteristic of any number of contemporary autofictions. In Eflriede Jelinek's avowedly autobiographical The Piano Teacher (1988) for example, both the character 'Erika Kohut' and the figure of 'SHE/HER' take the role of protagonist, and the story veers back and forth between these narrative points of view, an unsettling, even distracting mode of storytelling that draws attention to Jelinek's fictive ventriloquism. In Louise Erdrich's novel Shadow Tag (2010) the story of protagonist 'Irene America' is likewise multi-voiced and ambiguous as it is transmitted by two, contradictory diaries, the voice of her unstable and abusive husband Gil and by her young daughter Reil. The reader later discovers, moreover, that all of these narrative perspectives are themselves renderings by the adult Reil, who is writing about her childhood for her MFA degree. Another example is The Autobiography of my Mother (1996) by Jamaica Kincaid which is narrated by 'Xuela Claudette Robinson' a seventy-year-old woman with no children. In her storytelling, Xuela draws upon aspects of Kincaid's real life as well as her maternal grandmother's and as Xuela moves back and forth across time, the reader begins to understand that this text can never serve as a traditional autobiography of the mother Xuela never knew. Instead it is framed as a search for self-knowledge and agency outside of the historic subaltern role for a motherless mixed race woman growing up in colonized, patriarchal Dominica.

In each of these texts, and in others like them, the authors set out to complicate the accepted boundaries of truth and fiction, author, protagonist and narrator, and further to engage the reader not only in the consumption of plot content (of which there is often very little) but also in the transmission of representations of life experience across those boundaries. Marina Warner has 
argued that 'representation itself acts as a form of doubling; representation exists in magical relation to the apprehensible world, it can exercise the power to make something come alive, apparently' (165). And it is precisely this magical incarnation of experience, and the manner in which authors of autofiction constitute humanity through their rhetorical choices, that may make such narratives effective in, as James Dawes puts it, 'changing the world.'

\section{The Interesting}

That representative magic may not be wholly benign, of course. As noted earlier, Dawes, Slaughter, Esmeir and others have shown multiple, often troubling, links between literature and the advent of human rights discourse. Post-modern readings of the interesting likewise hint at our dominant cultural desire to compare one subject with another. Susan Sontag recognised this drive for comparability in the aesthetic of photography. As she argued, 'the photographic purchase on the world, with its limitless production of notes on reality,' makes everything comparable to others of its same type. By doing so, 'the practice of photography is now identified with the idea that everything in the world could be made interesting by the camera' (111). 'This quality of being interesting' Sontag warns, is 'empty,' and 'reductive,' because by 'disclosing the thingness of human beings, the humanness of things, photography transforms reality into a tautology,' and 'invites [...] an acquisitive relation to the world that nourishes aesthetic awareness and promotes emotional detachment' (111). In the repetitive act of acquisition and consumption, that is, the aesthetic of the interesting collapses. For when everything is interesting, nothing is.

Clinical psychologist Irene Bruna Seu examined the phenomenon of so-called 'compassion fatigue' in studies of audience reactions to fundraising appeals by Amnesty International. She found that such fatigue arose from widespread belief in Amnesty's interference in victims' narratives. There was, Seu noted, 'a striking mismatch' between the intentions of rights campaigners and audiences' 
reception of appeals, 'in that participants positioned themselves as critical and discerning consumers rather than moral agents' (444). Because they perceived an 'intractable connection' between rights campaigning and fundraising, the participants read appeals as 'openly cynical, mechanistic and manipulative' (444). As one put it: 'We give you the horror story; now give us your money' (444-5). The suffering of the rights abuse victims was erased by the very mechanism that sought to raise aid and awareness. Indeed, such appeals left Seu's subjects feeling that they were 'victims in need of protection,' from the manipulations of Amnesty's marketing material (445). The discerning eye of the comparing consumer paradoxically brought about detachment and lost 'interest' in the suffering of fellow human beings.

Sianne Ngai's account of the aesthetic category she labels the interesting negotiates the space between feeling/empathetic responses to art on the one hand and detached and purely cool aesthetic judgements on the other. For Ngai, it is the 'tension between individual and system that undergirds the interesting' which is 'preoccupied with the modern relationship between individuation and standardization' (7). Ngai lists the features of the interesting as 'semantic indefiniteness, affective ambiguity, recursive yet anticipatory temporality' (168). Situated within this liminal space, an aesthetic judgement that causes one to both reflect upon and anticipate the unfolding of discerning experiences in time, Ngai's interesting becomes the emblematic sign of autofiction. Like autofiction, the interesting 'inevitably diverts attention away from itself so as to throw the spotlight entirely on the question of its own legitimation' (169), a postmodern selfawareness that simultaneously highlights and obscures the veracity or otherwise of the factual details and 'real life' identities. In this way the reader of autofiction is made aware of the coexistence of the 'auto' and the 'fictive' in such texts: the narrator that is and is not the author, events that are and are not representative of real life, voices that are simultaneously human and text. While Jean-Louis Jeannelle has argued that in more traditional autobiographical 
Bildungsroman the narrator's status 'remains ambiguous' (26), that ambiguity is itself the essence of the autofictive narrative. By reading autofiction as both a response to and an enactment of the aesthetic category of the interesting, moreover, we can better consider how such ambiguous narratives might go about eliciting forms of empathy that could outwit contemporary compassion fatigue and ironic detachment.

For Sontag, the interesting is 'always connected to the relatively small surprise of information or variation from an existing norm' (111). In drawing attention to such variation, she argues, 'the interesting marks a tension between the unknown and the already known and is generally bound up with a desire to know and document reality' (111). In her study, Ngai considers Sontag's ideas via theories of art coolly 'regulated' by rational principles (6). ${ }^{2}$ Like the antigestural art of the 1960s, Ngai notes, the interesting 'directly echoes the [...] advocacy of detachment over enthusiasm as the proper artistic and critical attitude, promoted by Schlegel and other theorists of the 'interessante' in eighteenth-century Germany' (6). This tension between individual and system in the act of judging something interesting, explains 'why it also plays such a central role in conceptual art' which is 'a body of work similarly preoccupied with the modern relationship between individuation and standardization' (Ngai 7). If the postmodern highlights the signs and figures of which it is both constituted and a constituent, then the interesting is that judgement which allows one to stop and notice how clever such interplay can be.

\section{The Intersubjectivity of the Interesting}

Catherine Cusset argued that the practice of autofiction 'is anything but egocentric' (2). Instead, as Cusk's narrator Faye suggests, it is a 'discipline, almost of asceticism' in the service of its focus on 'the sum of human parts' (54). This urgent desire towards intersubjectivity and communication is

\footnotetext{
${ }^{2}$ See for example, Irving Sandler, 'The New Cool Art' (1965).
} 
central to Ngai's account of the interesting in which the 'compulsion to share or publicize that feeling [of interest], is the first step in activating interest in other subjects as well' (8). We not only see and frame an interesting image for ourselves, that is, but need to share it, for example, on social media, and await others' legitimation or challenge to our judgement. And beyond that, in our visually hectic lives, we continually find ourselves evaluating the relative interest of this or that meme, narrative, image, text. It is precisely this 'comparative dynamic,' as Ngai notes, that is 'the heart of aesthetic evaluation, since, as many have argued, there is no value without comparison' (26).

Like Sontag, then, Ngai argues that 'an object can never be interesting in and of itself, but only when checked against another: the thing against its description, the individual object against its generic type' (8). The result of this dynamic comparative process, is that what we label as interesting is in a constant state of flux, "both a curiously balanced and a curiously unstable aesthetic experience,' (26) a fleeting temporal judgement. This 'late twentieth century aesthetic of difference as information,' (112) ascribes value to things that seem to differ 'in a yet-to-beconceptualized way' from our expectation (112). ${ }^{3}$ Such judgements, moreover, are as Ngai argues, 'underpinned by a calm, if not necessarily weak, affective intensity' (112-13). The interesting, in other words, is not an entirely detached judgement, a careless flipping past of one image after another. Instead it is that which is different enough to cause one to stop and look, to assess that difference, and in that pause, to feel, however briefly, the affective message it conveys. In this way, I posit, the interesting may intrude upon the kind of cynical judgement offered by Bruna Seu's participants or even spur to real-world action the consumerist readership of multiple 'true stories'

\footnotetext{
${ }^{3}$ Note that 'interest' is derived from interesse, 'to be situated between' (Ngai 113.)
} 
of misery and testimonies of those who suffer atrocities. But what would that form of interesting look like?

Fact-based testimonials of the kind offered by rights campaigns or narratives of captivity, atrocity and suffering have begun to fall victim to the contemporary reader's sophistication, their awareness of literary codes, editorial interventions, and money-raising strategies. The more often such texts proclaim their tales of woe, the more firmly many readers shut their ears (and their wallets). Likewise, while fictional tales of suffering in films and novels may be commercially successful, they rarely lead to real-world change and risk alienating activist audiences with their oversimplified, poorly contextualised and repetitively redemptive narratives. ${ }^{4}$

As Adorno warned, the truths of past horrors may not be best served by metaphoric renderings. ${ }^{5}$ Autofiction, I would argue, is a form that comes closest to achieving moments of true intimacy between reader and subject matter. At their best, such texts engage readers' curiosity and empathy, precisely because they proclaim their fictional status while simultaneously hinting (via paratexts, such as author biographies, prefaces, photographs and the like) that there may be truths hidden within. In this way and others, autofictions are interesting. Their call to active readership does more than intrigue reader-detectives into fact-hunting: it slows down the process of the text's consumption. And when such texts deal with issues of identity politics, abuse, discrimination and other rights-related issues, autofictions enable an engagement that is a matter of ongoing thoughtful judgement and critique rather than mindless swallowing of yet another sad story.

\footnotetext{
${ }^{4}$ I am thinking here of books like The Boy in the Striped Pajamas or The Railway Man or The Reader and the films that arose from these, as well as films like Argo, Hotel Rwanda and even The Sound of Music.

${ }^{5}$ Theodor Adorno famously stated that 'Poetry after Auschwitz is barbaric.' Prisms (1967), 34. He troubled and expanded this prohibition in 'Elements of Anti-Semitism' in Adorno and Max Horkheimer Dialectic of Enlightenment (1944).
} 
Influenced by pioneering French novelists such as Marguerite Duras, Natalie Saurrat, Annie Ernaux and Hervé Guibert, many contemporary autofictions trouble not only genre boundaries but gendered ones, examining, exposing and interrogating sexual and gender politics and our understanding of desire itself. Writers such as Cusk, Karl Ove Knausgård and Elena Ferrante for example, draw upon the temporal demands of multivolume autofictions to induce readers to consider at great length the extraordinary power of words, ideas, images and everyday events. Other writers, such as Dave Eggers in What is the What: The Autobiography of Valentino Achak Deng or Jamaica Kincaid in The Autobiography of my Mother make a virtue of the hybrid genre's inherent tension between fact and language, the coexistence in autofiction of 'the demand for the truth' and the staging of their narrator(s) as explicitly textual. Such narratives can represent rights violations, atrocities and suffering in a manner that is, in the end, interesting.

Sianne Ngai develops Steven Knapp's argument that what is 'theoretically interesting' (Knapp 27) in literary studies is a 'gap between authorial intention and literary content that inevitably generates wonder about authorial agency' (Ngai 116). As a genre, autofiction is precisely located within that wonder-generating gap and there it gives witness not only to negotiations of genre codes and conventions, but also to the interesting's tension between the individual and the system. This complex articulation of coexisting concerns may in turn be generative of readers' affective, empathic engagement.

\section{Wonder Gap}

The aesthetic of the interesting is that which compares the individual outline against the generic type, searching for difference, and the interesting object is one that enacts that difference to some 
degree, temporarily destabilising our understanding of both individual and type and highlighting the space between them. Precisely this kind of process may be said to be at work in an autofiction such as Cusk's Outline, for example, a work in which the narrator becomes an all but invisible interlocutor, gathering the stories of a seemingly random series of characters she encounters: strangers on planes, students and fellow teachers at a writing retreat, a billionaire with whom she lunches. In each case this narrator, the facts of whose life coincide to a large degree with Cusk's own (as will be well-known to readers of her memoirs) may be seen to be sizing up these stories of relationship woe and gender inequality, of minor and major betrayals, against some ur-story of her own about which we are given only hints (we know only that Faye is a divorced mother, a writer, teaching in Greece, and is 'not interested in a relationship with any man, not now and probably not ever again' [178]).

Cusk's narrator comes 'to believe more and more in the virtues of passivity, and of living a life as unmarked by self-will as possible' (170) and the title of the novel derives from a character who, in conversation with a man, "began to see herself as a shape, an outline, with all the detail filled in around it while the shape itself remained blank,' and 'amorphous' (239-40). The interest for the reader of such a text (apart from the detective work that may be used to link Cusk's characters to 'the real world') is thus largely derived from the wonder gap between authorial intention and literary content, and the relation of these to narrative agency in the novel. In Outline, we are witness to Faye acting out the aesthetic judgement of what is of interest to her: those stories told by others that do not fit precisely into her outline, that may fall beyond its boundaries or fail to fill them in. By doing so, the text seems to suggest, the narrator seeks respite from, or perhaps confirmation of, the hegemony of the generic story of marriage and betrayal lodged so firmly in her mind. The radical detachment of the narrator, moreover, her very passivity, means that although 
the reader may not be emotionally affected by the text in the initial process of consumption, they can find themselves forced to return and reconsider its content, to share and debate its ideas with others, to measure Cusk's stories against others and determine Outline (whether or not they 'like it') as interesting.

And all this is possible because, as Ngai points out, the 'deepest content of the aesthetic category of the interesting is precisely that of the justification of aesthetic judgments in general' (233). As in autofiction, aesthetic judgements are at once the subject of, and the enactment of, the interesting. When we proclaim that we have judged something to be interesting, that is, we solicit 'a demand from another person to show them our evidence' and in that demand, that lengthening of engagement with the item of interest, the 'interesting extends what aesthetic evaluation might mean or encompass within its parameters: not just the spontaneous, feeling-based act of judgement but that judgement's discursive and narrative aftermath' (170).

Vladimir Nabokov wrote tellingly about just such a discursive and narrative aftermath of the interesting in his consideration of how aesthetic judgments informed his own autobiographicallyinterrogative narratives. In the memoir Speak Memory, he refers to two incidents in his life, linked by a single image: matchsticks. In the first, in his childhood, a friend of the family, General Kuropatkin, 'spread out to amuse me a handful of matches' and proceeded to perform a magic trick for young Vladimir. (23). Fifteen years later, he notes, 'at a certain point of my father's flight from Bolshevik-held St Petersburg' he was accosted by an old, bearded peasant who 'asked my father for a light. The next moment each recognized the other' (23). The dishevelled man is revealed to be the once formidable General Kuropatkin. The 'interest' in this story, however, lies less in that revelation than in the discursive swerve that Nabokov makes just afterward. 'I hope old Kuropatkin, in his 
rustic disguise, managed to evade Soviet imprisonment,' Nabokov writes, 'but that is not the point. What pleases me is the evolution of the match theme [...] The following of such thematic designs through one's life should be, I think, the true purpose of autobiography' (23).

The detachment and irony of Nabokov's observation here - that the pleasing symmetry of the match theme rather than Kuropatkin's survival was the real 'point' of the anecdote - is more than shocking - it is interesting. So much so that nearly every piece of criticism examining this text subjects this passage to scrutiny ${ }^{6}$ much in the same way that reviewers of Cusk's Outline took note of the passivity and near invisibility of the novel's narrator. ${ }^{7}$ In each case a strategy of swerving from the expected, of highlighting the author's privileging of form over content, of aesthetic value over affective manipulation not only draws initial attention, but compels reader/critics to defend, interrogate, debate and argue over the differences between these works and the generic conventions they set out to challenge. What Nabokov calls 'the true purpose of autobiography' may thus not be the thematic symmetry he suggests, but the ability to forge a narrative of one's life that is of interest to others.

As Isabelle Stengers has argued 'to interest someone in something means, first and above all, to act in such a way that this thing [...] can concern the person, intervene in his or her life, and eventually transform it' (83-4). Such transformation can only take place, however, when what is of interest to one person is shared, compared and discussed. 'What makes "interesting" of value,' Ngai states, 'is how it links heterogeneous agents or agencies together. More specifically, the judgment seems to create or facilitate kinds of 'betweenness' - relays. Conduits, associations - that in turn facilitate

\footnotetext{
${ }^{6}$ See for example Mikołaj Wiśnewski (2015); Juditg Varga (2012); Airella Freedman (2008): 77-9.

${ }^{7}$ See Heidi Julavitsjan (2015): BR10; James Lasdun (2014); Heller McAlpin (2015).
} 
the circulation of ideas, objects and signs' (113-4). The essence of the interesting, in other words, is its ability to forge connection.

When what we read points explicitly to textual negotiations, it compels us to consider what kinds of thoughts and feelings gave rise to such elaborate rhetorical strategies. The cumulative effect of that experience - the judgement of interesting - is an uncanny recognition at once Heimlich and unheimlich, both familiar and unfamiliar. In Erdrich's Shadow Tag, for example, competing versions of the plot vie for attention with the novelist's own revelation, rewriting, and truth-telling of aspects of her real, tragic family life. ${ }^{8}$ It is, like all autofiction, consumed by the fact of its own utterance, a story about story-telling, the point of which appears to be the production of the novel itself. The theme, like Nabokov's matchsticks, is not life at all, but the process of the autobiographical. And while in one sense portraying the suffering of others is unpleasant and possibly morally corrupt, this corruption and complexity makes it interesting, and that interest generates a specific kind of affective power for the reader (whatever its effect might be on Erdrich's family).$^{9}$

For Friedrich Schlegel in the eighteenth century, the interesting (interessante) was 'an experience with the possibility of difference,' with what 'makes a difference and with what could make oneself or a given state of affairs different' (cited in Mieszkowski 114). As we read autofiction stories of love and betrayal, domestic neglect and abuse, violence in conflict and other forms of rights violation, the affective power of such stories, derived from their interest to us, may compel us to linger, to discuss and debate and perhaps take up some mode of action to make things different.

\footnotetext{
${ }^{8}$ See Colin Colvert (2010).

${ }^{9}$ For a discussion of the impact of memoir writing on family members, and more specifically a discussion of its repercussions within Erdrich's own household, see Tom Couser (2004).
} 
Our reading may of course, as Dawes's research suggests, have the opposite effect and 'actively interfere' with the generation of empathy. Certainly, we will consider these issues for longer over the course of critiquing a text that articulates human experience through multiple, unreliable narrators and paratexts, discussing such representations with those whose judgements both concur with and diverge from ours. Such interesting work may thus engage us more strongly than a rights campaign poster or a novel whose story we believe to be entirely imaginary.

As Ngai notes, the interesting is all about this prolonged enactment of engagement and discussion. When we judge something as interesting, she argues, we are 'essentially making a plea for extending the period of the act of aesthetic evaluation: let us keep on talking about this [...] We tell people we find works interesting when we want to do criticism' (233). Intersubjectivity is thus the framework of both the interesting and the autofictional.

Ngai concludes that 'the aesthetic of the interesting has the capacity to produce new knowledge' (170). In autofiction, this new knowledge is devised and constructed jointly through the performance and evidentiary support of our aesthetic judgement in relation to the interesting object/text and others' views of its relative value. And the result of this complex interaction is, as Ngai argues:

the formation of a historically specific kind of aesthetic subject: 'us.' the judgment of the object as 'interesting,' with all its glaring conceptual indeterminacy, almost seems designed to facilitate the subject's formation of ties with another subject: the 'you' whose subsequent demand for concept-based explanation might be read as the feeling-based judgment's secret goal. (233-4) 
Autofiction, via the conceptual complexity and indeterminancy of the interesting, constitutes humanity as a distinctive kind of aesthetic subject, one whose intersubjectivity generates an intimate version of 'literary empathy,' an intimacy, that may, finally, support and enable empathetic and rights-advancing humanity.

\section{Cited Works}

Adorno, Theodor. Prisms. 6th Ed. Trans. Samuel and Shierry Weber. Cambridge, Mass: MIT Press, 1967.

Adorno T. and Max Horkheimer. 'Elements of Anti-Semitism.' Dialectic of Enlightenment (1944) Trans. John Cumming. London: Verso, 1997. 168-208.

Buckley, Jerome. 'Autobiography in the English Bildungsroman.' The Interpretation of Narrative: Theory and Practice. Ed. Morton Bloomfield. Cambridge, MA: Harvard University Press, 1980.

Chaulet-Achour, Christiane. Noûn. Algériennes dans l'écriture. Biarritz:

Atlantica, 1998.

Covert, Colin. 'The Anguished Life of Michael Dorris'. Star Tribune (Minnesota), February 102010.

Couser, G.T. Vulnerable Subjects. Cornell University Press, 2004.

Cusk, Rachel. Outline. New York: FSG, 2014.

Cussett, Catherine. 'The Limits of Autofiction.' Unpublished Conference Paper, 2012.

Dawes, James. 'Human Rights in Literary Studies.' Human Rights Quarterly 31:2 (2009): 394-409.

---. 'Human Rights, Literature, and Empathy.' The Routledge Companion to Literature and Human Rights. Eds. Sophia McClennen and Alexandra Schultheis Moore, London: Routledge, 2015. 427-32.

Doubrovsky, Serge. Fils. Paris: Galilée, 1977.

Eggers, Dave. What is the What? The Autobiography of Valentino Achak Deng: A Novel London: Hamish Hamilton, 2007.

Erdrich, Louise. Shadow Tag. New York: Harper Collins, 2010.

Esmeir, Samera. 'On Making Dehumanization Possible.' PMLA 125.5 (2006): 1544 -52. 
Ferreira-Meyers, Karen. 'Autobiography and Autofiction: No Need to Fight for a Place in the Limelight, There is Space Enough for Both of these Concepts.' Writing the Self: Essays on Autobiography and Autofiction. Eds. Kerstin W. Shands, Giulia Grillo Mikrut, Dipti R. Pattanaik, Karen Ferreira-Meyers. Printed in Sweden by Elanders, English Studies 5, 2015. 203-18.

Forest, Phillipe. 'Je \& Moi : Avant-propos.' Nouvelle Revue Française: Je \& Moi 598 (Fall, 2011): 720.

---. 'Post-scriptum: 'll faut continuer, je ne peux pas continuer, je vais continuer." In Burgelin, Claude, Grell, Isabelle and Roche, Roger-Yves (dir.). Autofiction(s). Colloque de Cerisy. Lyon: Presses universitaires de Lyon. (2010): 127-44.

Freedman, Ariella. 'Theories of Memory: Developing a Canon.' Journal of Modern Literature 32:1 (2008): 77-9.

Hunt, Lynn. Inventing Human Rights: A History. New York: WW Norton, 2008.

Jeannelle, J. L., and C. Violet. Genèse et Autofiction. Louvain-la-Neuve: Academia Bruylant, 2007.

Jelinek, Elfriede. The Piano Teacher. London: Serpent's Tail, 1989.

Jensen, Meg. 'The Legible Face of Human Rights in Autobiographical Fiction.' The Routledge Companion to Literature and Human Rights. London: Routledge, 2015, 184-92.

---. 'Surviving the Wreck: Post-traumatic Writers, Bodies in Transition and the point of Autobiographical Fiction.' LifeWriting 14:1 (2017): 431-48.

---. 'We Shall Bear Witness': Life Narratives and Human Rights. Co-ed Margaretta Jolly. Madison: Wisconsin University Press, 2014.

Heidegger, Martin. What is Called Thinking? New York: Harper and Row, 1968.

Julavitsjan, Heidi. 'The Stories We Tell: Rachel Cusk's Outline.' New York Times, Sunday Book Review (January 11, 2015): BR10.

Kincaid, Jamaica. The Autobiography of My Mother. New York: FSG, 1997.

Knapp, Steven. Literary Interest: The Limits of Anti-Formalism. Cambridge, MA: Harvard University Press, 1993.

Lasdun, James. 'Outline by Rachel Cusk review.' The Guardian, Books (September 3, 2014) <https://www.theguardian.com/books/2014/sep/03/outline-rachel-cusk-review-novel>

Laurens, Camille. 'Dialogue entre nous.' Nouvelle Revue Française: Je \& Moi 598 (Fall, 2011): 14050 .

McAlpin, Heller. 'There's Nothing Sketchy About This Outline.' NPR Books online (January 13, 2015) <http://www.npr.org/2015/01/13/376093557/theres-nothing-sketchy-about-this-outline> 
Mieszkowski, Jan. Labours of Imagination: Aesthetics and Political Economy from Kant to Althusser. New York: Fordham University Press, 2006.

Nabokov, Vladimir. Speak Memory: An Autobiography Revisited. New York: Penguin, 1966.

Ngai, Siane. Our Aesthetic Categories: Zany, Cute, Interesting. Cambridge: Harvard University Press, 2012.

Sandler, Irving. 'The New Cool Art.' Art in America 53.1 (February 1965): 99-101.

Seu, Irene Bruna. 'Doing Denial: Audience Reaction to Human Rights Appeals.' Discourse \& Society 21.4 (2010): 438-57.

Slaughter, Joseph. Human Rights, Inc. New York: Fordham University Press, 2007.

Sontag, Susan. On Photography. New York: FSG, 1977.

Stengers, Isabelle. Power and Invention: Situating Science. Trans. Paul Bains. Minneapolis: University of Minnesota Press, 1997.

Varga, Juditg. 'Looking Autobiographically: Rethinking the Mirror Metaphor and the Enigma of Autobiography.' Life Writing 9:3 (2012): 291-301.

Warner, Marina. Fantastic Metamorphoses, Other Worlds (Clarendon Lectures in English). Oxford: Oxford University Press, 2002.

Wiśnewski, Mikołaj. 'Retouching the Past: Vladimir Nabokov's Speak, Memory as Fictive Autobiography' in Writing the Self (2015): 307-14. 